\title{
Radial variation of wood density components and ring width in cork oak trees
}

\author{
Sofia KNAPIC ${ }^{\text {, }}$ José L. LOUZAdA ${ }^{\mathrm{b}}$, Sofia LEAL ${ }^{\mathrm{a}}$, Helena PEREIRA ${ }^{\mathrm{a} *}$ \\ ${ }^{a}$ Centro de Estudos Florestais, Instituto Superior de Agronomia, Universidade Técnica de Lisboa Tapada da Ajuda 1349-017 Lisboa, Portugal \\ ${ }^{\mathrm{b}}$ Departamento Florestal, Universidade de Trás-os-Montes e Alto Douro, Portugal
}

(Received 15 February 2006; accepted 24 October 2006)

\begin{abstract}
The radial variation of ring width and wood density was studied in cork oaks (Quercus suber) using microdensitometry. The observations were made in young never debarked cork oaks (30-40 years of age) and in mature trees under cork production (37-60 years of age). The cork oak wood is very dense (mean ring density $0.86 \mathrm{~g} . \mathrm{cm}^{-3}$, between $0.79 \mathrm{~g} . \mathrm{cm}^{-3}$ and $0.97 \mathrm{~g} . \mathrm{cm}^{-3}$ ) with a small intra-ring variability (mean earlywood density $0.80 \mathrm{~g} . \mathrm{cm}^{-3}$ and latewood density $0.90 \mathrm{~g} . \mathrm{cm}^{-3}$ ). The density components decreased from pith to bark more rapidly until the 15 th ring, and then only slightly. There were no significant differences in the mean density components between never debarked trees and trees under cork production but their outwards decrease was accentuated in the never debarked trees. The annual growth was high, with a ring width mean of $3.9 \mathrm{~mm}(4.2 \mathrm{~mm}$ in the first 30 years) and the latewood represented $57 \%$ of the annual growth.
\end{abstract}

Quercus suber / cork oak / density / ring width / latewood

Résumé - Variation radiale des composantes de la microdensité du bois et de la largeur de cerne dans le chêne-liège. La variation radiale de la largeur des cernes et de la densité du bois a été étudiée dans le chêne-liège (Quercus suber) par microdensitométrie. Les observations ont été réalisées dans des arbres jeunes jamais écorcés (âge 30-40 ans) et des arbres en phase de production de liège (37-60 ans). Le bois de chêne-liège est très dense (densité moyenne $0,86 \mathrm{~g} \cdot \mathrm{cm}^{-3}$, variant entre $0,79 \mathrm{~g} \cdot \mathrm{cm}^{-3}$ et $0,97 \mathrm{~g} \cdot \mathrm{cm}^{-3}$ ) avec une variabilité dans le cerne faible (densité moyenne du bois initial $0,80 \mathrm{~g} \cdot \mathrm{cm}^{-3}$ et du bois final $0,97 \mathrm{~g} \cdot \mathrm{cm}^{-3}$ ). Les composantes de la densité diminuent du cœur à la périphérie rapidement jusqu' au $15^{\mathrm{e}}$ cerne, puis plus lentement. Les différences entre valeurs moyennes des composantes de la densité du bois des arbres non écorcés et écorcés ne sont pas statistiquement significatives, quoique la diminution radiale soit plus accentuée dans les arbres non écorcés. La croissance annuelle était élevée avec une largeur moyenne de cerne de $3,9 \mathrm{~mm}(4,2 \mathrm{~mm}$ dans les premiers $30 \mathrm{ans})$ avec le bois final correspondant à $57 \%$ de la croissance annuelle.

Quercus suber / chêne-liège / densité / largeur de cerne / bois final

\section{INTRODUCTION}

Oaks are valuable timber species and oak wood is highly regarded for indoor joinery and furniture due to its mechanical properties and aesthetical value. Size and absence of defects such as knots or grain direction are also important aspects for acceptance of oak timber for higher value products. Considerable research has been carried out to characterise oak wood properties and their variation. Wood density is one of the most important properties since it correlates well to many other physical properties, namely to mechanical strength and performance in use. Oak wood density has been studied extensively, i.e. for Quercus robur and Q. petraea in France [2,5,11,21]. Most of the studies dealing with the within-tree and betweentree variation of wood density have used X-ray microdensitometric techniques as developed by Polge [33,34].

The cork oak (Quercus suber L.) occupies large areas around the western Mediterranean basin in Southern Europe and North Africa, over a total area of about 2 million ha, mainly in Portugal (725000 ha) and Spain (475000 ha). Most

\footnotetext{
*Corresponding author: hpereira@ isa.utl.pt
}

of the Quercus suber forests integrate an agro-forest system that combines forest, agriculture and animal production, called "montado" in Portugal and "dehesa" in Spain [32]. During the last century, the cork oak forests have been directed towards the production of cork, with a silviculture and management oriented towards the sustainable removal of the tree outer bark. It is therefore not strange that research has concentrated on cork [17] and cork production related issues, i.e. production modelling $[14,37,40,41]$, and little has been done on cork oak wood characterization.

With the present cork oak forest management, the rotation is long and when the trees are harvested the wood is used only as an energy biomass. Nowadays no effort is made to value the wood component. However cork oak wood is a strong and aesthetic wood, and it was formerly highly prized for demanding uses such as shipbuilding.

A diversification of cork oak and cork oak forests utilization has been consistently advised as a strategic approach to guarantee the sustainability of these systems. The potential of cork oaks for production of high value wood products and the future availability of considerable amounts of thinning material from 
Table I. Model for analysis of variance for the density components of cork oak trees.

\begin{tabular}{|c|c|c|c|}
\hline Sources of variation & Degrees of freedom & Error term & Expected mean squares \\
\hline (1) Groups & $s-1$ & (2) & $\sigma_{\varepsilon}^{2}+\mathrm{r} \sigma_{\mathrm{T} / \mathrm{S}}^{2}+\operatorname{tr} \sigma_{\mathrm{S}}^{2}$ \\
\hline (2) Trees/Groups & $(t-1) s$ & (5) & $\sigma_{\varepsilon}^{2}+\mathrm{r} \sigma_{\mathrm{T} / \mathrm{S}}^{2}$ \\
\hline (3) Rings & $r-1$ & (5) & $\sigma_{\varepsilon}^{2}+$ ts $\sigma_{\mathrm{R}}^{2}$ \\
\hline (4) Rings $\times$ Groups & $(r-1)(s-1)$ & (5) & $\sigma_{\varepsilon}^{2}+\mathrm{t} \sigma_{\mathrm{RS}}^{\mathrm{n}^{\mathrm{n}}}$ \\
\hline (5) Residual $(\mathrm{R} \times \mathrm{T} / \mathrm{S})$ & $(r-1)(t-1) \mathrm{s}$ & & $\sigma_{\varepsilon}^{2}$ \\
\hline
\end{tabular}

$s=$ number of groups (2); $r=$ number of rings $(30) ; t=$ number of trees/groups (estimated in 3.43 according to the formula proposed by Sokal and Rohlf [39], p. 214). $\sigma_{\mathrm{S}}^{2}, \sigma_{\mathrm{T} / \mathrm{S}}^{2}, \sigma_{\mathrm{R}}^{2}, \sigma_{\mathrm{RS}}^{2}$, and $\sigma_{\varepsilon}^{2}$ are variance components due to groups, trees/groups, rings, rings $\times$ groups interaction and residual (or error), respectively.

areas planted during the last two decades led us to research cork oak wood growth and properties.

In this paper we present X-ray microdensitometric data obtained for cork oaks and study the variation with age of ring width and of the density components for two groups of trees: young and never debarked trees, and mature trees under cork production with a 9-year extraction cycle.

\section{MATERIAL AND METHODS}

The cork oak (Quercus suber L.) trees used for this study were felled in 1998 in the cork production region of Alentejo in Southwestern Portugal, in low-density stands typical of the montado agroforestry system. The trees were available for study from legal fellings due to road construction since there is a legal ban to harvest cork oaks. The trees presented good vitality and phytosanitary conditions.

The climate is of the Mediterranean type, with a mean temperature of $16.1{ }^{\circ} \mathrm{C}$ and hot summers with the highest mean temperatures occurring in July and August (ca. $23^{\circ} \mathrm{C}$ ). The annual rainfall is $607 \mathrm{~mm}$, concentrating from October to April and close to zero in the summer months.

A total of seven trees were sampled divided into two groups: four mature cork oaks under full production of cork with a 9 year cycle (coded M1 to M4), with a stem wood diameter at $1.3 \mathrm{~m}$ ranging $39 \mathrm{~cm}$ to $43 \mathrm{~cm}$; and three younger trees from which cork was never removed (coded $\mathrm{Y} 1$ to $\mathrm{Y} 3$ ), with a stem wood diameter at $1.3 \mathrm{~m}$ ranging $27 \mathrm{~cm}$ to $34 \mathrm{~cm}$. For the mature trees the last cork removal was in 1996. The date of the first cork removal was not recorded (this is the rule for most mature cork oaks in production), but it is estimated as having occurred at about 25 years of age.

From each tree a $4 \mathrm{~cm}$-thick disk was taken at breast height $(1.3 \mathrm{~m})$, and was sawn into a $2 \mathrm{~mm}$-thick radial strip segment from the pith to the bark. The strips were conditioned at $12 \%$ moisture content. These radial samples were $\mathrm{X}$-rayed perpendicularly to the transverse section and their image scanned by microdensitometric analysis as described by Polge $[33,34]$. The time of exposure to radiation was $350 \mathrm{~s}$, at an intensity of $18 \mathrm{~mA}$ and an accelerating tension of $12 \mathrm{kV}$, with a $2.5 \mathrm{~m}$ distance between X-ray source and film. The data composing the radial density profiles were recorded every $100 \mu \mathrm{m}$ with a slit height (tangential direction) of $455 \mu \mathrm{m}$. The choice of a $100 \mu \mathrm{m}$ radial windows was due to the fact that the species is a hardwood, with large vessels with average diameters over $100 \mu \mathrm{m}$ and attaining in large vessels values over $200 \mu \mathrm{m}$ [25]. A smaller size for the radial windows would lead to higher amplitude of the variation of density within the rings and, therefore, to a higher number of density peaks within the ring, which would make it more difficult to identify the rings.

The growth ring boundaries were identified on the radial profiles by locating the sharp density variations with a cross-examination using a visual observation of the macroscopic anatomical features namely the vessel distribution. For each ring, average ring density (RD), minimum density (MND), maximum density (MXD), earlywood density (EWD), latewood density (LWD), ring width (RW) and latewood percentage (LWP) were determined. The earlywood and latewood in each growth ring were calculated using the average of the minimum and maximum density values within each ring for their distinction, i.e. the $\mathrm{LW}$ was calculated from all the points with a density higher than this average value $[11,28,36]$. Therefore, this criterion does not allow to identify the beginning of the latewood, but only the portions of the ring with a density higher than a certain threshold, which we call here LW. The intra-ring density variation was quantified by the heterogeneity index (HI) proposed by Ferrand [16], defined by the standard deviation of all density values across the annual ring.

Analyses of variance for all density components were performed according to the model presented in Table I to test the significance of tree group (never debarked, and under cork production), trees and rings (age) effects. Variance components for the sources of variation were also estimated.

\section{RESULTS}

\subsection{Radial density profiles}

The radial density profiles obtained for the cork oaks are exemplified on Figure 1. The boundary between two consecutive growth rings was characterised by a decrease in density as shown in Figure 1a. However the between-ring variation of density was not very large and in many cases the ring boundary identification was ambiguous when using only densitometric data (as in Fig. 1b). Therefore cross-examination with anatomical features was necessary in numerous cases, especially in the mature trees under cork production. It was impossible to use only automatic data treatment for ring definition and the vessel distribution in the cross-section was applied in combination with the density profiles. Therefore the experimental data processing was complex and very time consuming. 
Table II. Number of rings, mean ring width and density features for the studied cork oak trees (M1-M4, mature trees under cork production; Y1-Y3 never debarked cork oaks). Mean of all rings and standard deviation.

\begin{tabular}{lcccccc}
\hline Trees & Number of rings & Ring width $(\mathrm{mm})$ & Ring density $(\mathrm{g} / \mathrm{cm} 3)$ & Earlywood density $(\mathrm{g} / \mathrm{cm} 3)$ & Latewood density $(\mathrm{g} / \mathrm{cm} 3)$ & Latewood \% \\
\hline M1 & 60 & $3.37 \pm 1.68$ & $0.87 \pm 0.18$ & $0.82 \pm 0.18$ & $0.91 \pm 0.18$ & $56.1 \pm 16.5$ \\
M2 & 59 & $2.10 \pm 0.55$ & $0.75 \pm 0.06$ & $0.69 \pm 0.07$ & $0.79 \pm 0.06$ & $54.6 \pm 9.0$ \\
M3 & 57 & $3.44 \pm 2.09$ & $0.85 \pm 0.11$ & $0.78 \pm 0.11$ & $0.89 \pm 0.11$ & $61.1 \pm 14.5$ \\
M4 & 37 & $5.34 \pm 3.06$ & $0.88 \pm 0.07$ & $0.83 \pm 0.07$ & $0.92 \pm 0.07$ & $57.5 \pm 16.6$ \\
Y1 & 39 & $4.17 \pm 1.96$ & $0.89 \pm 0.13$ & $0.82 \pm 0.14$ & $0.93 \pm 0.12$ & $56.9 \pm 14.4$ \\
Y2 & 34 & $4.56 \pm 1.75$ & $0.82 \pm 0.09$ & $0.76 \pm 0.10$ & $0.86 \pm 0.09$ & $56.5 \pm 12.5$ \\
Y3 & 29 & $4.31 \pm 1.81$ & $0.95 \pm 0.12$ & $0.89 \pm 0.11$ & $0.99 \pm 0.12$ & $56.2 \pm 9.7$ \\
\hline
\end{tabular}

(a)

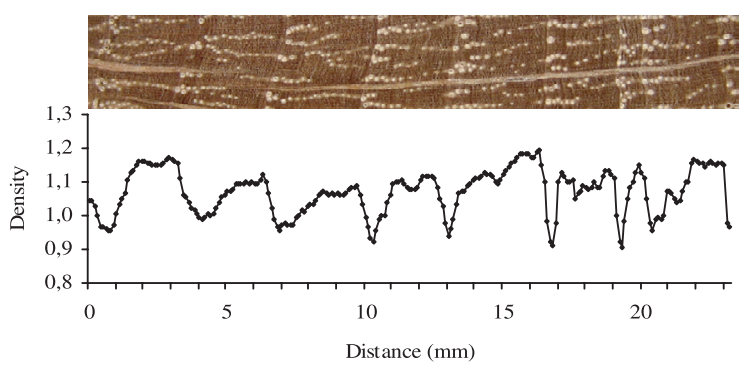

(b)

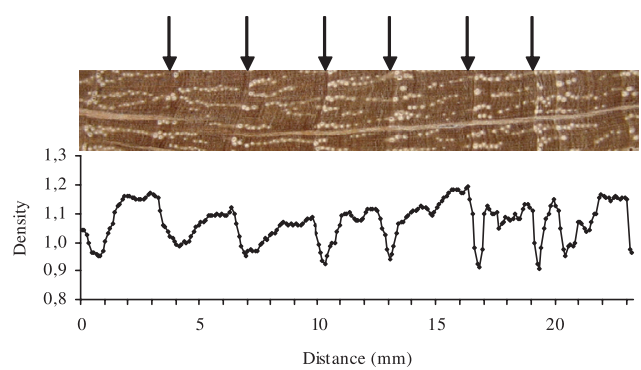

Figure 1. Radial density profile for cork oak trees and the corresponding transverse wood section. (a) 7th to 13th rings of one never debarked tree (b) approximately 42 th to 47 th rings of one mature tree under cork production (the arrows indicate the rings).

\subsection{Mean ring and density features}

Table II shows the number of rings, the average annual growth, and the mean density components for each tree. The mean annual growth was $3.9 \mathrm{~mm} \mathrm{yr}^{-1}$ ranging in individual trees from $2.1 \mathrm{~mm} \mathrm{yr}^{-1}$ to $5.3 \mathrm{~mm} \mathrm{yr}^{-1}$. The cork oak wood revealed a very high mean density that ranged between $0.75 \mathrm{~g}$ $\mathrm{cm}^{-3}$ and $0.95 \mathrm{~g} \mathrm{~cm}^{-3}$, with an average earlywood density of $0.80 \mathrm{~g} \mathrm{~cm}^{-3}$ and latewood density of $0.90 \mathrm{~g} \mathrm{~cm}^{-3}$. The latewood corresponded on average to $57 \%$ of the annual growth.

\subsection{Ring width variation}

Figure 2 shows the variation of ring width with age for the individual trees. There were inter-annual fluctuations of growth but an age related trend of ring width was not very clear. It is noteworthy that the ring width did not decrease below $1 \mathrm{~mm}$ and often increased over $5 \mathrm{~mm}$. The accumulated
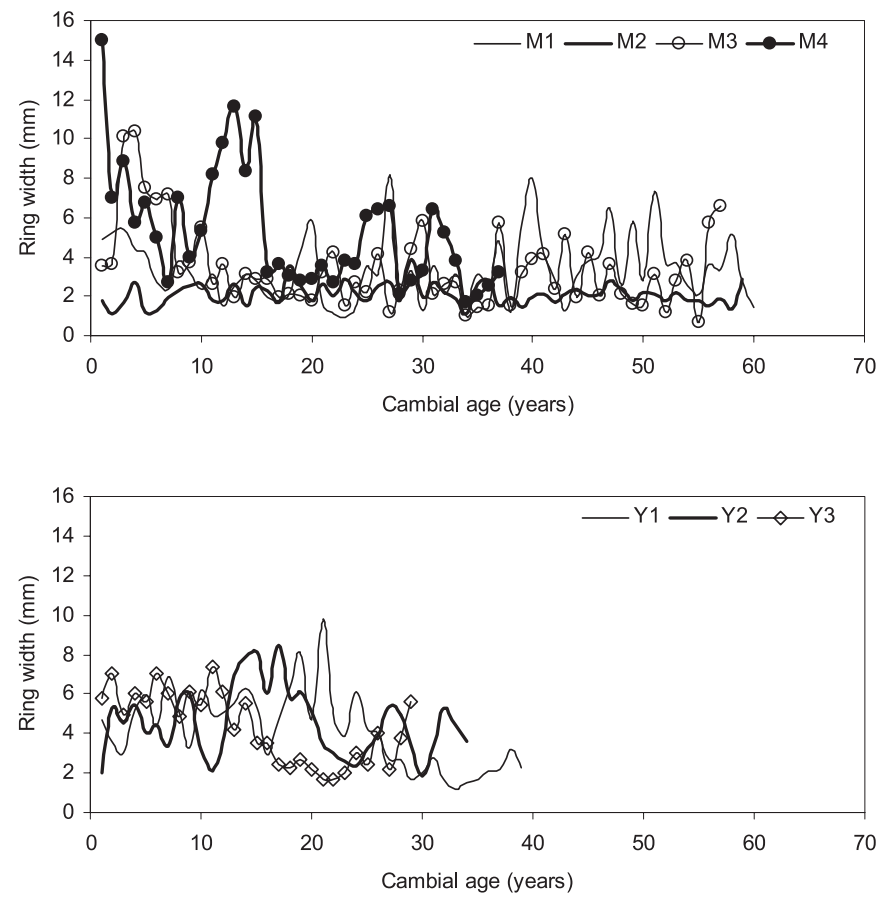

Figure 2. Variation of ring width with cambial age for the cork oaks under cork production (M1-M4) and for the never debarked trees (Y1-Y3).

growth curves are shown in Figure 3. The mean annual growth was higher in the first 20 years for five of the trees but in two trees (the slowest growing ones) ring width was uniform along the years.

The proportion of latewood growth in the ring varied between $54.6 \%$ and $61.1 \%$ between years and did not present an age-related variation trend (Fig. 4). There was no relation between annual growth and proportion of latewood growth (Fig. 5).

\subsection{Density variation with age and growth}

Figure 6 shows the variation of ring mean density with age. There was an average decrease of density in the first 20-30 years with a subsequent stabilization but overall the radial variation of mean density was small. There was no relation between ring width and mean ring density (Fig. 7). 


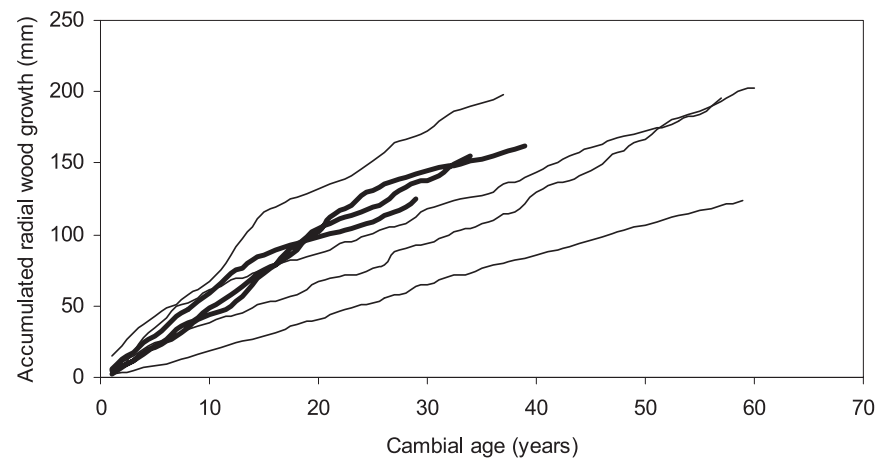

Figure 3. Accumulated radial wood growth with age for the cork oaks (full lines for $\mathrm{M}$ and thicker lines for $\mathrm{Y}$ ).

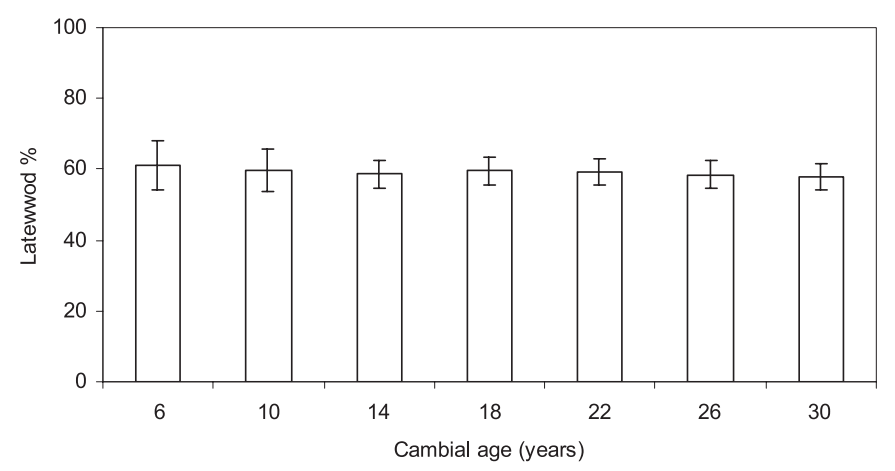

Figure 4. Variation of latewood proportion in different growth rings.

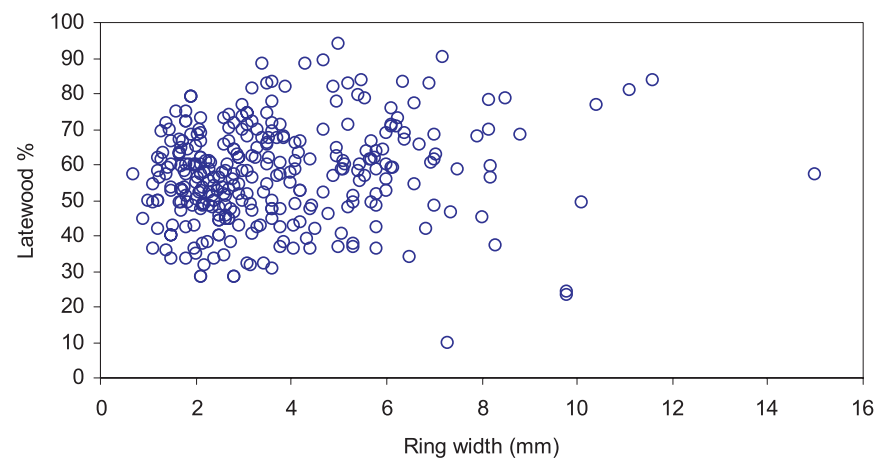

Figure 5. Variation of latewood proportion with ring width for the seven cork oak trees.

Within the ring the heterogeneity index was very low with an average of 0.05 and without variation with ring number. The density difference between earlywood and latewood was small (on average $0.10 \mathrm{~g} \mathrm{~cm}^{-3}$, Tab. II) and constant radially.

\subsection{Analysis of variation of ring and density components}

An analysis of variance was made on the ring and density components using the data for the first 30 rings that were common to all the trees. The corresponding descriptive statistics for the trees are given in Table III. Table IV shows the results
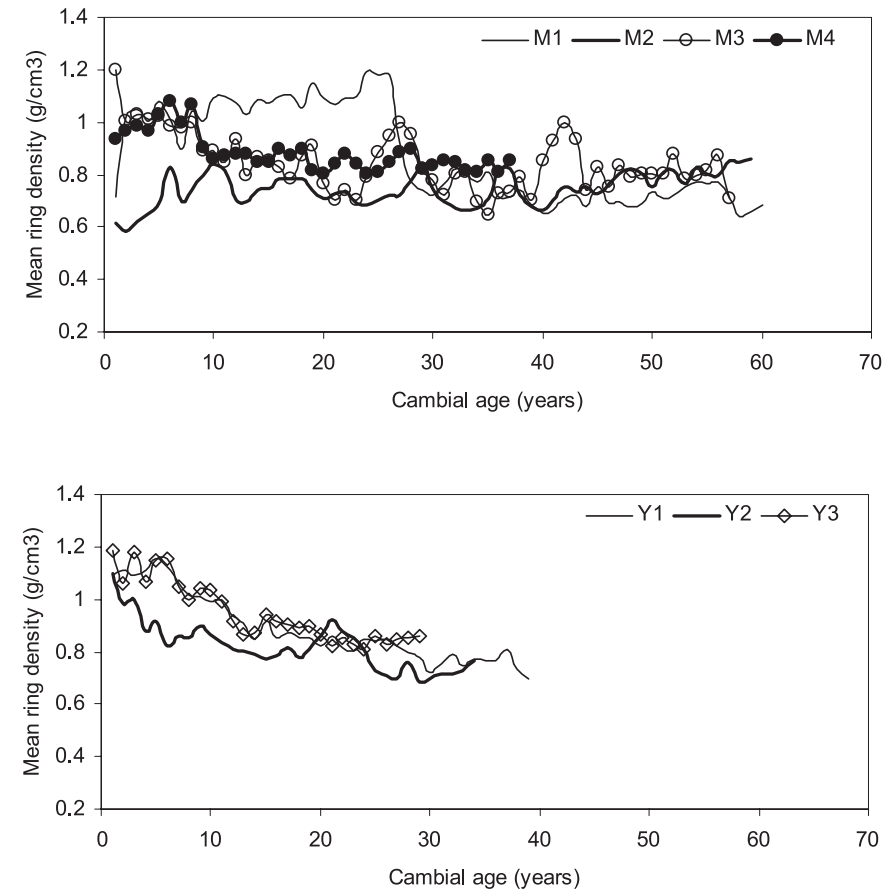

Figure 6. Variation of mean ring density with age for seven cork oak trees.

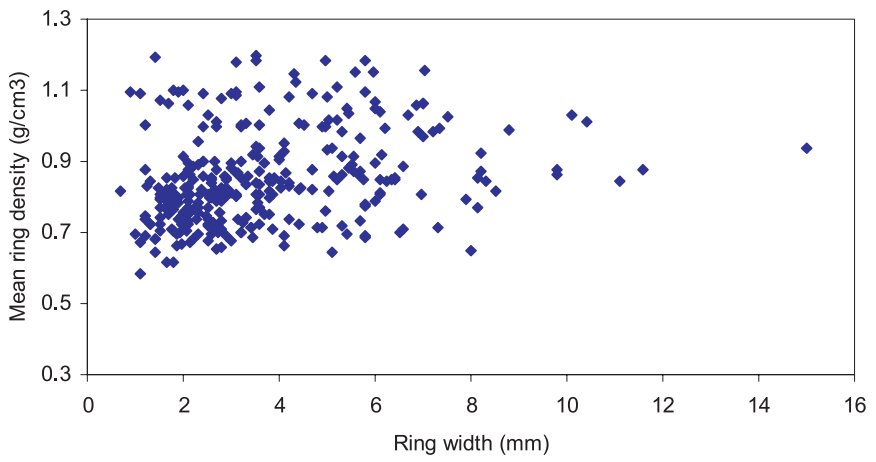

Figure 7. Variation of mean ring density with ring width for the seven cork oak trees.

obtained regarding the statistical significance and proportion of explained variation for the different sources of variation.

There were no significant differences between the two groups of trees for all the variables. In most cases the betweentree variation was very highly significant and accounted for most of the total variation. The age effect given by the between-ring variation was highly significant to explain the variation in the density component variables but contributed less to the total variation, e.g. $45.6 \%$ and $12.7 \%$ of the total mean density variation respectively for the tree and age effects.

The variability was slightly higher in the group of trees under cork production (even if between group variance was equal), as reflected by the higher coefficients of variation of the means (Tab. III). The heterogeneity index had only a small variability and it was not influenced by the studied factors (Tabs. III and IV). 
Table III. Descriptive statistics for ring width and density components for the two types of cork oak trees (under cork production and never debarked cork oaks) for the first 30 rings.

\begin{tabular}{|c|c|c|c|c|c|c|c|c|c|}
\hline \multirow{2}{*}{ Trait } & \multirow{2}{*}{$\begin{array}{c}\text { Global } \\
\text { mean }\end{array}$} & \multicolumn{4}{|c|}{ Never debarked trees } & \multicolumn{4}{|c|}{ Under cork production trees } \\
\hline & & Mean & Min. & Max. & $\mathrm{CV}(\%)$ & Mean & Min. & Max. & $\mathrm{CV}(\%)$ \\
\hline $\mathrm{RD}$ & 0.894 & 0.901 & 0.832 & 0.947 & 6.74 & 0.886 & 0.730 & 1.025 & 12.07 \\
\hline MND & 0.792 & 0.797 & 0.724 & 0.848 & 8.13 & 0.787 & 0.647 & 0.929 & 14.64 \\
\hline MXD & 0.974 & 0.984 & 0.919 & 1.030 & 5.90 & 0.964 & 0.810 & 1.091 & 12.01 \\
\hline EWD & 0.835 & 0.841 & 0.773 & 0.890 & 7.23 & 0.828 & 0.683 & 0.965 & 13.94 \\
\hline LWD & 0.933 & 0.942 & 0.873 & 0.990 & 6.54 & 0.923 & 0.775 & 1.056 & 12.47 \\
\hline HI & 0.052 & 0.054 & 0.052 & 0.055 & 2.30 & 0.051 & 0.048 & 0.056 & 7.43 \\
\hline RW (mm) & 4.17 & 4.59 & 4.35 & 4.80 & 4.94 & 3.75 & 2.18 & 5.75 & 40.36 \\
\hline $\operatorname{LWP}(\%)$ & 57.81 & 57.07 & 56.40 & 58.13 & 1.62 & 58.54 & 52.17 & 62.55 & 8.14 \\
\hline
\end{tabular}

$\mathrm{RD}$, average ring density; MND, minimum density; MXD, maximum density; EWD, earlywood density, LWD, latewood density; RW, ring width; LWP, latewood percentage; HI, heterogeneity index.

Table IV. Summary of the variance analysis for each wood density component and ring width, showing their significance and the percentage of total variation due to each source of variation.

\begin{tabular}{|c|c|c|c|c|c|c|c|c|c|c|c|c|c|c|c|c|}
\hline \multirow[t]{2}{*}{ Sources of variation } & \multicolumn{2}{|c|}{$\mathrm{RD}$} & \multicolumn{2}{|c|}{ MND } & \multicolumn{2}{|c|}{ MXD } & \multicolumn{2}{|c|}{ EWD } & \multicolumn{2}{|c|}{ LWD } & \multicolumn{2}{|c|}{$\mathrm{HI}$} & \multicolumn{2}{|c|}{ RW } & \multicolumn{2}{|c|}{ LWP } \\
\hline & Sig. & $\%$ & Sig. & $\%$ & Sig. & $\%$ & Sig. & $\%$ & Sig. & $\%$ & Sig. & $\%$ & Sig. & $\%$ & Sig. & $\%$ \\
\hline Group & ns & 0.0 & ns & 0.0 & ns & 0.0 & ns & 0.0 & ns & 0.0 & ns & 0.2 & ns & 0.0 & ns & 0.0 \\
\hline Tree/Group & $* * *$ & 45.6 & $* * *$ & 39.4 & $* * *$ & 43.4 & $* * *$ & 41.1 & $* * *$ & 44.1 & ns & 0.0 & $* * *$ & 22.8 & ns & 3.6 \\
\hline Ring & $* * *$ & 12.7 & $* *$ & 6.6 & $* * *$ & 15.6 & $* * *$ & 8.3 & $* * *$ & 13.7 & ns & 7.3 & ns & 2.9 & ns & 0.05 \\
\hline Ring $\times$ group & $*$ & 6.8 & ns & 5.1 & $*$ & 5.9 & ns & 5.9 & $*$ & 7.5 & ns & 0.0 & ns & 0.0 & ns & 1.8 \\
\hline Residual & & 34.9 & & 48.9 & & 35.1 & & 44.6 & & 34.8 & & 92.5 & & 74.3 & & 94.6 \\
\hline
\end{tabular}

RD, average ring density; MND, minimum density; MXD, maximum density; EWD, earlywood density, LWD, latewood density; RW, ring width; LWP, latewood percentage; HI, heterogeneity index.

In relation to ring width the tree effect was very highly significant and accounted for $22.8 \%$ of the total variation. The between-tree differences were higher in the group of mature trees in cork production where the average tree ring width ranged between $2.2 \mathrm{~mm}$ and $5.8 \mathrm{~mm}$, while in the trees before cork extraction it ranged between $4.4 \mathrm{~mm}$ and $4.8 \mathrm{~mm}$. The latewood component in the ring width remained particularly constant and was not significantly influenced by any of the studied sources of variation.

\section{DISCUSSION}

In spite of the difficulty in identifying ring boundaries and the resulting necessity in many cases of cross-examination with anatomical data, overall the density profiles obtained for the cork oak (Fig. 1a) showed that there was a trend for the decrease in density in the transition from the latewood of one ring to the earlywood of the next year that could be used to mark ring boundaries. This difference is related to the anatomical ring structure regarding vessel distribution. The cork oak has a semi-diffuse porosity with large vessels formed in the beginning of the growing season that gradually decrease to the end of the ring. This pattern is usually well defined in young cork oaks before about 20 years of cambial age (ring number from the pith) but become later on more confused especially in the case of older cork oaks under cork production [20]. Ring distinction may not be obvious as exemplified by the density profile of Figure 1b. A visual cross-examination with the wood strip was therefore necessary to clear out uncertainties. This process was certainly tedious and required a trained eye for observation of cork oak wood anatomical features.

With an average density of $0.86 \mathrm{~g} . \mathrm{cm}^{-3}$ and mean tree values ranging from $0.75 \mathrm{~g} . \mathrm{cm}^{-3}$ to $0.95 \mathrm{~g} . \mathrm{cm}^{-3}$ (Tab. II), the wood of Quercus suber is very dense compared to other hardwoods. It shows values identical to some tropical species such as Apidosperma, Bowdichia, Chlorofora, and Dalbergia $[15,22,31,42]$. In what concerns European hardwoods, $Q$. suber is in general much denser than their majority. In relation to other Quercus it shows average values identical to $Q$. pendunlata $\left(0.82 \mathrm{~g} . \mathrm{cm}^{-3}\right), Q$. cerris $\left(0.85 \mathrm{~g} . \mathrm{cm}^{-3}\right)$ and $Q$. ilex $\left(0.96 \mathrm{~g} . \mathrm{cm}^{-3}\right)$, or higher than $Q$. petraea $(0.51-$

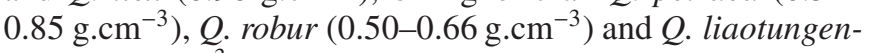
sis $\left(0.66\right.$ g.cm $\left.{ }^{-3}\right)[6,11,12,43-45]$.

One important characteristic of the cork oak wood was its low intra-ring variability with small differences between earlywood and latewood densities, as well as between minimum and maximum densities, which translated into a very small ring heterogeneity index (Tabs. II and III). This heterogeneity index is in the same order as the $0.05-0.06$ reported for the very homogeneous poplar wood [38] and below the mean 0.13 reported for Pinus pinaster wood [27], also considered a homogeneous softwood [3]. It must be stressed that the calculation of latewood proportion only refers to the amount of the ring with a density above the threshold given by the average of minimum and maximum density. This method [11,28,36] has the advantage of identifying the LW in a fast way and compatible with the microdensitometric analysis by X-ray, a reason 
why it is so frequently utilised in this type of analysis. However this provides no biological boundary between earlywood and latewood. It is true that the method used here was established for other oak species characterized by a different ring typology (i.e. ring porous). We tested at an initial phase of this work an alternative method using one fixed value of density as threshold, as it has been used by other authors, namely in softwoods $[1,4,9,10,13,18,23,24,30,35]$. The method however did not seem appropriate for this wood, since many rings would have been made only of EW or LW.

These results therefore advise the need for further studies to develop a method specific for a semi diffuse ring typology, as it is the case of cork oak.

In general the radial variation of cork oak wood density was small. There was a decrease of the density components in the first 30 years (more abrupt up to the 15th ring) with a subsequent stabilisation (Fig. 6). This pattern of radial variation is relatively frequent in hardwoods $[15,46]$, including some Quercus such as $Q$. garryana, $Q$. petraea and $Q$. robur $[11,12,21,26,43,44]$.

The analysis of variance (Tab. IV) confirmed the small magnitude of the radial variation of the density components. Although highly significant the effect of ring only accounted for $13 \%$ of the total variation of the mean density and most variation was due to the between-tree differences $(46 \%$ of the total variation). There were no differences between the two types of trees although some difference could be observed in relation to the variation of wood density components with age (Fig. 6), as confirmed statistically by a significant difference with the ring $\times$ group effects accounting for $7 \%$ of the total variation (Tab. IV). The never debarked trees (Y-trees) showed a clear decrease of the density components with age in the first 30 rings, while the trees that had been already debarked (Mtrees) showed a much smoother reduction of density. Usually there is an accumulation of extractives in the first rings corresponding to the heartwood, which contributes for the high values of density in that region. Since this was not observed in the studied trees, it may be speculated that after the debarking there is a tree response to prevent wood degradation and favour the scar formation with a displacement of extractives from heartwood to the outer sapwood, thereby reducing wood density in the innermost rings and increasing it in the outward rings. Until the beginning of cork extraction the accumulation of extractives should contribute to the higher density values found in the innermost rings, as seen for the Y-trees in Figure 6 . Therefore in trees under cork production there will be an outwards directed radial shift of extractives leading to a relative stabilization of density along the radius in these trees.

It could also be observed that it was in the group of the trees under cork production that the between-tree variation of the density components was higher (Tab. III). This may result from a difference in the individual tree response capacity to the cork extraction trauma. However the response of the cork oak to the removal of cork and the factors that influence it are still a matter requiring further research.

Finally, although $Q$. suber is usually considered as a slow growing species, in the case of the sampled trees the mean annual growth was $3.9 \mathrm{~mm}$ (4.2 $\mathrm{mm}$ in the first 30 years)
(Tabs. II and III). This is a high value compared with the ring widths between $1.53 \mathrm{~mm}$ and $1.90 \mathrm{~mm}$ reported for $Q$. petraea and $Q$. robur, and the value of $2.19 \mathrm{~mm}$ for $Q$. liaotungensis [11,12,43-45]. Very little information is available for $Q$. suber but ring widths of $2 \mathrm{~mm}^{\mathrm{yr}} \mathrm{yr}^{-1}$ for young trees [29] and values ranging from $1 \mathrm{~mm}$ to $4 \mathrm{~mm}_{\mathrm{yr}} \mathrm{yr}^{-1}$ in mature cork oaks $[19,20]$ have been reported. Indirect calculations have estimated an average radial wood increment of $1.3 \mathrm{~mm} \cdot \mathrm{yr}^{-1}$ in one 8 -year period following a cork extraction in mature cork oaks in full cork exploitation [8].

There was an important variation of ring width between different years (Fig. 2) that could not be attributed neither to cambial age nor to tree (Tab. IV), and most of the ring width variation (74\% of the total variation) was not accounted for. The effect of climatic variation from year to year is probably one of the explanations since it is known that cork oak radial growth is positively related to rainfall $[7,8]$. The same explanation may apply to the variation of latewood proportion (95\% of the variation not accounted for (Tab. IV).

The relatively high growth rate of the $Q$. suber trees, associated to a high density, disclose a large capacity of biomass production, thus revealing itself as an interesting species for fixing carbon, especially when considering the type of environments where cork oaks grow.

\section{CONCLUSIONS}

The Quercus suber wood is very dense and has a small intra-ring variability regarding differences between earlywood and latewood as well as between minimum and maximum density values. The ring density and its components tend to decrease from pith to bark more rapidly up to the 15 th ring, and then only slightly. The radial patterns of the density components were slightly different between debarked and undebarked trees. For the never debarked trees, the density components decreased outwards much more than in the debarked trees.

The high density and density homogeneity of cork oak wood confirm its value for use in some solid wood applications and the opportunity to consider the wood component in the silviculture and long term management of cork oak stands. Additionally to the high density, the substantial annual growth rates of $Q$. suber also advise to consider its role for biomass production and carbon storage, especially taking into account its natural growth environment.

Acknowledgements: This study was partially funded by the European project SUBERWOOD (QLK5-CT-2000-00701) within the 5th Research Framework Programme, the Portuguese project SOBRO (AGRO 523) within the AGRO and FEDER programme. The Centro de Estudos Florestais is a research unit funded by FCT (Fundação para a Ciência e Tecnologia, Portugal) within the POCTI-FEDER programme.

\section{REFERENCES}

[1] Abdel-Gadir A.Y., Krahmer R.L., McKimmy M.D., Intra-ring variations in mature Douglas-fir trees from provenance plantations, Wood Fiber Sci. 25 (1993) 170-181. 
[2] Ackermann F., Relationship between forest site and intra-ring wood density components for the pedunculate oak (Quercus robur L.) of southwestern France, Ann. Sci. For. 52 (1995) 635-652.

[3] Aubert M., Relations entre l'hétérogénéité d'épaisseur des placages de cinq essences résineuses ( $P$. sylvestris, $P$. strobus, Pseudotsuga menziesii, P. pinaster, Picea excelsa) déroulés en conditions préindustrielles et les composantes densitométriques de leur bois, DEA Science du Bois, I.N.P.L., Université de Nancy I, 1984, 67 p.

[4] Barbour R.J., Fayle D.C.F., Chauret G., Cook J., Karsh M.B., Ran S., Breast-height relative density and radial growth in mature jack pine (Pinus banksiana) for 38 years after thinning, Can. J. For. Res. 24 (1994) 2439-2447.

[5] Bergès L., Dupouey J.L., Franc A., Long-term changes in wood density and radial growth of Quercus petraea Liebl. in northern France since the middle of the nineteenth century, Trees 14 (2000) 398-408.

[6] Bonamini G., Un nuovo criterio per il raggruppamento razionale delle specie legnose in base alla massa volumica, Monti e Boschi 47 (1996) 34-38.

[7] Costa A., Pereira H., Oliveira A., A dendroclimatological approach to diameter growth in adult cork oak trees under production, Trees 15 (2001) 438-443.

[8] Costa A., Pereira H., Oliveira A., Influence of climate on the seasonality of radial growth of cork oak during a cork production cycle, Ann. For. Sci. 59 (2002) 429-437.

[9] Cown D.J., Parker M.L., Comparison of annual ring density profiles in hardwoods and softwoods by X-ray densitometry, Can. J. For Res. 8 (1978) 442-449.

[10] DeBell J.D., Tappeiner J.C.II, Krahmer R.L., Wood density of western hemlock: effect of ring width, Can. J. For. Res. 24 (1994) 638641.

[11] Degron R., Nepveu G., Prévision de la variabilité intra- et interarbre de la densité du bois de chêne rouvre (Quercus petraea Liebl.) par modélisation des largeurs et des densités des bois initial et final en fonction de l'âge cambial, de la largeur de cerne et du niveau dans l'arbre, Ann. Sci. For. 53 (1996) 1019-1030.

[12] Deret-Varcin E., Étude comparative de la qualité du bois de trois types de chênes (rouvres, pédonculés et intermédiaires), en forêt de Morimond, Ann. Sci. For. 40 (1983) 373-398.

[13] Dodd R.S., Power A.B., Population variation in wood structure of white fir, Can. J. For. Res.24 (1994) 2269-2274

[14] Falcão A.O., Borges J.G., Designing decision support tools for Mediterranean forest ecosystems management: a case study in Portugal, Ann. For. Sci. 62 (2005) 751-760.

[15] Fearnside P.M., Wood density for estimating forest biomass in Brazilian Amazonia, For. Ecol. Manage. 90 (1997) 59-87.

[16] Ferrand J.C., Réflexions sur la densité du bois. $2^{\mathrm{e}}$ Partie : Calcul de la densité et de son hétérogénéité, Holzforschung 36 (1982) 153157.

[17] Fortes M.A., Rosa M.E., Pereira H., A Cortiça, Editora IST Press, Lisboa, 2004.

[18] Fujisawa Y., Ohta S., Tajima M., Wood characteristics and genetic variations in sugi (Cryptomeria japonica). II. Variation in growth ring components among plus trees clones and test stands, Mokuzai Gakkaishi (J. Japan Wood Res. Soc.), 39 (1993) 875-882.

[19] González-Adrados J.R., Gourlay I., Applications of dendrochronology to Quercus suber L., in: Pereira H. (Ed.), Cork oak and cork, Proceedings of the European Conference on Cork Oak and Cork, Centro de Estudos Florestais, Lisboa, Portugal, 1998, pp. 162-166.

[20] Gourlay I., Pereira H., The effect of bark stripping on wood production in cork oak (Quercus suber L.) and problems of growth ring definition, in: Pereira H. (Ed.), Cork oak and cork, Proceedings of the European Conference on Cork Oak and Cork, Centro de Estudos Florestais, Lisboa, Portugal, 1998, pp. 99-107.
[21] Guilley E., Hervé J.C., Huber F., Nepveu G., Modelling variability of within-ring density components in Quercus petraea Liebl. with mixed-effect models and simulating the influence of contrasting silvicultures on wood density, Ann. For. Sci. 56 (1999) 449-458.

[22] Hidayat S., Simpson W.T., Use of green moisture content and basic specific gravity to group tropical woods for kiln drying, Forest Products Laboratory, Research Note FPL-RN-0263 (1994) 39 p.

[23] Hodge G.R., Purnell R.C., Genetic parameter estimates for wood density, transition age, and radial growth in slash pine, Can. J. For. Res. 23 (1993) 1881-1891.

[24] Keller R., Xeuxet D., Méthode de la mesure des données microdensitométriques et de leur traitement à l'ordinateur, Communication présentée au Congrès de l'IUFRO, Le Cap, Prétoria, SeptembreOctobre, 1973, 22 p.

[25] Leal S., Sousa V.B., Pereira H., Radial variation of vessel size and distribution in the wood of cork oak (Quercus suber L.). Wood Sci. Technol. (2006), in press.

[26] Lei H., Milota M.R., Gartner B.L., Between- and within-tree variation in the anatomy and specific gravity of wood in oregon white oak (Quercus garryana Dougl.), IAWA J. 17 (4) (1996) 445-461.

[27] Louzada J.L., Fonseca F., The heritability of wood density components in Pinus pinaster Ait. and the implications for tree breeding, Ann. For. Sci. 59 (2002) 867-873.

[28] Mothe F., Sciama D., Leban J.-M., Nepveu G., Localisation de la transition bois initial-bois final dans un cerne de chêne par analyse microdensitométrique, Ann. For. Sci. 55 (1998) 437-449.

[29] Nunes E., Estudo da influência da precipitação e temperatura no crescimento juvenil de Quercus suber L. através dos anéis anuais de crescimento, Dissertation, Instituto Superior de Agronomia, Universidade Técnica de Lisboa, Lisboa, Portugal, 1996.

[30] Park Y.I., Dallaire G., Morin H., A method for multiple intra-ring demarcation of coniferous trees, Ann. For. Sci. 63 (2006) 9-14.

[31] Parolin P., Radial gradients in wood specific gravity in trees of central amazonial floodplains, IAWA J. 23(4) (2002) 449-457.

[32] Pereira H., Tomé M., Cork oak, in: Burley J. (Ed.), Encyclopedia of Forest Sciences, Elsevier Ltd., Oxford, UK, 2004, pp. 613-620.

[33] Polge H., Établissement des courbes de variation de la densité du bois par exploration densitométrique de radiographies d'échantillons prélevés à la tarière sur des arbres vivants Applications dans les domaines technologique et physiologique, Ann. Sci. For. 23, 1966.

[34] Polge H., Fifteen years of wood radiation densitometry, Wood Sci. Technol. 12 (1978) 187-196.

[35] Polge, H., Study of wood density variations by densitometric analysis of X-ray negatives of samples taken with a Pressler auger, IUFRO, Section 41 (1965) $19 \mathrm{p}$.

[36] Rozenberg Ph., Franc A., Cahalan C., Incorporating wood density in breeding programs for softwoods in Europe: a strategy and associated methods, Silvae Genet. 50 (2001) 1-7.

[37] Sanchez-Gonzalez M., Tomé M., Montero G., Modelling height and diameter growth of dominant cork oak trees in Spain, Ann. For. Sci. 62 (2005) 633-643.

[38] Silva M.E., Louzada, J.L., Utilização da microdensitometria por raios-x na avaliação qualitativa da madeira de choupo (Populus $\times$ euramericana. CV I.214), I Simposio del Chopo, Zamora, Espanha (2001) 469-478.

[39] Sokal R.R., Rohlf F.J., Biometry - The principles and practice of statistics in biological research, 2nd ed., W.H. Freeman and Company, New York, 1981.

[40] Tomé M., Coelho M.B., Lopes F., Pereira H., Modelo de produção para o montado de sobro em Portugal, in: Pereira H. (Ed.), Cork oak and cork, Proceedings of the European Conference on Cork Oak and Cork, Centro de Estudos Florestais, Lisboa, Portugal, 1998, pp. 22-46. 
[41] Vasquez J., Pereira H., Mixed models to estimate tree oven-dried cork weight in Central and Southern Portugal, For. Ecol. Manage. 213 (2005) 117-132.

[42] Williams R.S., Miller R., Gangstad, J., Characteristics of ten tropical hardwoods from certified forests in Bolivia. Part I. Weathering characteristics and dimensional change, Wood Fiber Sci. 33 (2001) 618-626.

[43] Zhang S.Y., Variations and correlations of various ring width and ring density features in European oak: implications in dendroclimatology, Wood Sci. Technol. 31 (1997) 63-72.
[44] Zhang S.Y., Owoundi R.E., Nepveu G., Mothe F., Dhôte J.F., Modelling wood density in european oak (Quercus petraea and Quercus robur) and simulating the silvicultural influence, Can. J. For. Res. 23 (1993) 2587-2593.

[45] Zhang S.Y., Zhong, Y., Effect of growth rate on specific gravity of east-liaoning oak (Quercus liaotungensis) wood, Can. J. For. Res. 21 (1991) 255-260.

[46] Zobel B.J., van Buijtenen J.P., Wood variation - Its causes and control, Springer Series in Wood Science, Ed: Timell T.E., SpringerVerlag, 1989. 